\title{
Gastro-jejunal digestion of soya-bean-milk protein in humans
}

\author{
BY AGNES BAGLIERI ${ }^{1}$, SYLVAIN MAHE ${ }^{*}$, SEMIA ZIDI ${ }^{2}$, JEAN-FRANCOIS \\ HUNEAU ${ }^{1}$, FRANCOIS THUILLIER ${ }^{2}$, PHILIPPE MARTEAU ${ }^{2}$ AND DANIEL \\ TOME ${ }^{1}$ \\ ${ }^{1}$ Institut National de la Recherche Agronomique, Unité de Nutrition Humaine et de Physiologie \\ Intestinale, Faculté des Sciences Pharmaceutiques et Biologiques, 4 avenue de l'Observatoire, 75006 \\ Paris, France \\ ${ }^{2}$ Service de Gastro-entérologie, INSERM U290, Hôpital Saint-Lazare, 107 rue de Faubourg Saint- \\ Denis, 75010 Paris, France
}

(Received 22 July 1993 - Revised 6 December 1993-Accepted 14 January 1994)

\begin{abstract}
In order to determine how soya-bean proteins are digested and metabolized in the human intestine before colonic bacterial fermentation and to estimate their true digestibility, the gastro-jejunal behaviour of soya-bean proteins in water and in two other forms (a concentrated soya-bean-protein solution (isolate) and a drink composed of crude soya-bean proteins (soymilk)) was studied in humans. Experiments were carried out in eight healthy volunteers using a double-lumen steady-state intestinal perfusion method with polyethyleneglycol (PEG) as a non-absorbable volume marker. Gastric emptying and $\mathrm{N}$ and electrolyte contents of the jejunal digesta were analysed. Gastric half-emptying time (min) of the liquid phase after water ingestion (12.59 (SE 0.12)) was shorter $(P<0.05)$ than those for soymilk (37.74 (SE 11.57)) and isolate (36.52 (SE 11.23)). Electrolytic balances showed that for all meals, $\mathrm{Na}^{+}, \mathrm{Cl}^{-}$and $\mathrm{K}^{+}$were secreted when $\mathrm{Ca}^{2+}$ was efficiently absorbed from the jejunal lumen. Gastro-jejunal $\mathrm{N}$ absorption for isolate and soymilk were 63 and $49 \%$ respectively, and were not significantly different from one another; after water ingestion, endogenous $\mathbf{N}$ was estimated to be $21 \mathrm{mmol}$. An estimate of the exogenous: endogenous values for the effluents was obtained from the amino acid compositions of soymilk and effluents after water or soymilk ingestion, indicating that $70 \%$ of the total $N$ was exogenous and $30 \%$ endogenous. Under these conditions the endogenous fraction represented $31 \mathrm{mmol}$ after soymilk ingestion and the gastro-jejunal $\mathrm{N}$ balance indicated that $54 \%$ of the soymilk was absorbed. This finding indicates that the true gastrojejunal digestibility of soya-bean proteins is similar to that of milk proteins.
\end{abstract}

Soya-bean protein: Digestibility: Humans

In contrast with Asian cuisine, soya-bean proteins have not traditionally represented a significant component in the Western diet, except for vegetarians. However, the relative contribution of soya-bean proteins to human nutrition is bound to increase because of its low cost, high availability, excellent functional properties in food systems, and continued innovative food-product development (Young et al. 1979, 1984; Wolf, 1981; Beer et al. 1989; Erdman \& Fordyce, 1989; Cheng et al. 1990). Short-term and long-term metabolic studies with soya-bean products showed that soya-bean proteins are potentially an excellent source of $\mathbf{N}$ in relation to meeting physiological needs, and that their nutritional value is comparable with that of milk, meat and eggs (Wayler et al. 1983; Young et al. 1984; Beer et al. 1989). Soya-bean proteins are also used as a milk substitute for infants intolerant to milk protein; however, soya-bean-protein allergies have also been observed (Taylor et al. 1987).

For food legumes, protein digestibility is important in relation to protein quality, but

* For reprints. 
little information is available on the digestion of soya-bean proteins in humans. To our knowledge, studies on apparent digestibility achieved in humans consuming soya-bean proteins mainly concern the measurement of faecal losses of $\mathrm{N}$. The bioavailability of plant proteins is related to the presence of trypsin inhibitors and lectins which could possibly impair protein digestibility and bioavailability (Grant, 1989). Most of the antinutritional effects of legumes are removed by thermal treatment but even with this treatment legumeprotein digestibility values are often less than those obtained from animal proteins (Bressani \& Elias, 1977). Thus, it is important to know how soya-bean proteins are digested and metabolized in the upper intestine of humans before they are subjected to colonic bacterial fermentation.

The present work was designed to study gastro-jejunal transit and digestibility of soyabean protein in humans. For this purpose, subjects were given orally a concentrated soyabean-protein solution (isolate) and a drink composed of crude soya-bean protein (soymilk). Jejunal digesta were collected and gastric emptying, meal liquid-phase transit, $\mathbf{N}$ and electrolyte contents were measured. Estimates of the exogenous and endogenous $\mathrm{N}$ fractions in the intestinal contents were obtained by comparing the amino acid compositions of the diets and the intestinal digesta using an iterative procedure (Guilloteau et al. 1983).

\section{METHODS}

Diets

Two different meals were tested (Table 1): $400 \mathrm{ml}$ soymilk and $400 \mathrm{ml}$ isolate. Water (Vittel, France) was used as the control. Isolate and soymilk were supplied by Laiterie Triballat (Noyal-sur-Vilaine, France) and contained 12.8 and $14.5 \mathrm{~g}$ protein respectively. Each meal was adjusted to $925 \mathrm{kBq}$ with $\left[{ }^{14} \mathrm{C}\right]$ polyethylene glycol (molecular weight $4000 ;{ }^{14} \mathrm{C}-\mathrm{PEG}$ $4000)$ as the non-absorbable liquid-phase marker.

\section{Subjects}

Eight healthy female volunteers, aged from 24 to 39 (mean 31) years, weighing from 56 to 67 (mean 60) $\mathrm{kg}$ and between 1.63 and 1.73 (mean 1.68) $\mathrm{m}$ in height, were selected according to the following criteria: (1) no history of gastrointestinal symptoms or surgery; (2) absence of any disorders of the gastrointestinal system; (3) absence of pregnancy; (4) a stable, satisfactory nutritional status and a stable body weight. The protocol was approved previously by the Ethical Committee of the Saint-Lazare Hospital (Paris 75010, France). Consent was obtained from all subjects before participation in the study.

\section{Intestinal perfusion technique}

A double-lumen steady-state intestinal perfusion method (Modigliani et al. 1973) with polyethylene glycol (molecular weight 4000; PEG-4000) as the non-absorbable volume marker was used to calculate the absorption rate of water and solutes (Fordtran, 1966). Volunteers swallowed one gastric and one jejunal tube as previously described (Mahé et al. 1992). The tip of the gastric tube was sited in the antrum and was used for sampling postprandial gastric contents in order to determine the meal marker concentrations $\left({ }^{14} \mathrm{C}-\right.$ PEG-4000). The jejunal tube was used: (1) to perfuse PEG-4000 into the duodenum and (2) to aspirate the jejunal contents. The perfusion site of PEG- 4000 was located at the angle of Treitz and the aspiration site $200 \mathrm{~mm}$ distally.

\section{Experimental design}

The test was divided into three consecutive days during which subjects were provided daily with one of the two test meals (soymilk or isolate) or water (control), each patient being 
Table 1. Composition of $400 \mathrm{ml}$ test meals

\begin{tabular}{lccc}
\hline \hline & Soymilk* & Isolate† & Water \\
\hline Proteins (g) & $14 \cdot 5$ & $12 \cdot 8$ & 0 \\
Lipids (g) & $4 \cdot 4$ & $<0.08$ & 0 \\
Carbohydrates (g) & 1 & $<0 \cdot 03$ & 0 \\
Na (mg) & 120 & 163 & $1 \cdot 2$ \\
Cl (mg) & 39 & 43 & 0 \\
K (mg) & 226 & 15 & $2 \cdot 2$ \\
Ca (mg) & 75 & 30 & $80 \cdot 8$ \\
Mg (mg) & 48 & 10 & $14 \cdot 4$ \\
\hline \hline
\end{tabular}

* A drink composed of crude soya-bean proteins.

$\dagger$ A concentrated soya-bean-protein solution.

her own control. On the night before the test the subjects had dinner at 20.00 hours and then fasted overnight. Starting at 08.00 hours, the positions of the jejunal and gastric tubes were verified under radioscopic control. At $20 \mathrm{~min}$ before meal ingestion and during the whole test period a saline solution $(150 \mathrm{mM}-\mathrm{NaCl})$ containing PEG-4000 $(10 \mathrm{~g} / \mathrm{l})$ was perfused into the duodenum at a rate of $2 \mathrm{ml} / \mathrm{min}$. Every $20 \mathrm{~min}$, gastric contents were aspirated using a manual syringe. Jejunal aspirates were obtained by continuous suction through the distal opening of the jejunal tube, collected on ice and samples pooled for each $20 \mathrm{~min}$ period. The $20 \mathrm{~min}$ before meal ingestion were considered as the initial period. After $4 \mathrm{~h}$ the gastric contents were completely aspirated and the stomach was washed with $200 \mathrm{ml}$ saline solution.

\section{Analytical methods}

The volume and $\mathrm{pH}$ of the effluents were measured after homogenization. The effluents were treated with $0.1 \mathrm{~mm}$-diisopropylfluorophosphate (Sigma) to prevent enzymic degradation of proteins, then frozen at $-20^{\circ}$ and freeze-dried. In jejunal samples the PEG4000 was measuring using the turbidimetric method of Hyden (1955). In jejunal and gastric samples, ${ }^{14} \mathrm{C}$ radioactivity measurements were made using a well-type scintillation counter. The total $\mathrm{N}$ content was determined by the pyrochemiluminescence technique (Gorimar $e t$ al. 1984) using an Antek $771 \mathrm{C}$ pyroreactor and $720 \mathrm{C}$ chemiluminescent $\mathrm{N}$ detector (Sopares, Gentilly, France). Osmolality was established by measuring the freezing-point of the solutions with a micro-osmometer (Advanced Instruments, Inc., Needham Heights, MA, USA). The $\mathrm{Na}^{+}$and $\mathrm{K}^{+}$concentrations were determined using a flame photometer (Corning 480; Ciba-Corning, Cergy-Pontoise, France) and the $\mathrm{Cl}^{-}$concentration by the coulometric method (Corning 925; Ciba-Corning, Cergy-Pontoise, France). The $\mathrm{Ca}^{2+}$ and $\mathrm{Ma}^{2+}$ concentrations were measured by automatic atomic absorption spectrophotometry (Kem O Mat 2; Coultronics France S.A., Andilly, France).

\section{Protein precipitation of diets and jejunal effluents}

Ethanol $(700 \mathrm{ml} / 1 ; 1 \mathrm{ml})$ and hexane $(1 \mathrm{ml})$ were added to portions of freeze-dried samples (corresponding to about $1 \mathrm{mg} \mathrm{N}$ ) of the diets as well as the effluents. After vigorous mixing and then standing for $1 \mathrm{~h}$ at $4^{\circ}$ the protein was separated by centrifugation at $2400 \mathrm{~g}$ for $30 \mathrm{~min}$ at $4^{\circ}$. The upper hexane layer which contained lipids was discarded and the ethanol fraction collected. The protein-containing pellet was washed once more with $1 \mathrm{ml}$ ethanol using the same time-course. Both ethanol supernatant fractions were combined. The pellet and the supernatant fractions were dried under reduced pressure with a speed-vac 
concentrator. The pellet was considered to consist of proteins and the dried supernatant fractions to contain peptides and free amino acids.

\section{Amino acid compositions}

Amino acid compositions of soymilk and jejunal effluents after water and soymilk ingestion were determined after acid-hydrolysis $\left(110^{\circ}, 24 \mathrm{~h}, 6 \mathrm{M}-\mathrm{HCl}\right.$, under vacuum), with a Beckman, System 6300, High Performance Amino Acid Analyser (Beckman, Palo Alto, CA, USA). Cysteine and tryptophan were not determined.

\section{Calculation and statistical analysis}

The postprandial volume of the gastric contents was calculated using ascending recurrence according to Malagelada et al. (1976) and improved by Vidon et al. (1979). The mathematical adjustment of the curves for gastric emptying of the liquid phases was performed using a non-linear regression procedure (NLIN, SAS 6.03; SAS Institute Inc., Cary, NC, USA) as follows: VR $=\exp \left(-a t^{b}\right)$, where VR is the proportion of the meal remaining in the stomach at a given time $(t), a$ is the slope of the exponential and $b$ is a factor introduced to account for an initial delay in gastric emptying (Elashoff et al. 1982). The flow-rate of the effluents (V) was calculated from the concentration of PEG-4000 and corrected for perfusion volume $(2 \mathrm{ml} / \mathrm{min})$ as follows: $\mathrm{V}=\left(\mathrm{PEG}_{\mathrm{p}} / \mathrm{PEG}_{\mathrm{e}}\right) \times \mathrm{D}$, where $P G_{p}$ is the concentration of perfused PEG, $P E G_{e}$ is the $P E G$ concentration in the effluents and $D$ is the perfused PEG flow-rate. Exogenous fractions in the effluents were estimated by comparing the amino acid compositions of the diets and the intestinal effluents using an iterative procedure (Guilloteau et al. 1983). The model used, $F=a A+b B+\epsilon$, was interpreted to estimate the respective $\mathrm{N}$ proportions whose origin was either dietary $(A)$ or endogenous $(B)$. The coefficients $a, b, \epsilon$ were determined by the minimum square method, with $a+b=1$ (SAS Institute Inc., 1990). Results were expressed as means with their standard errors and statistical analysis was performed using variance analysis, Tukey's studentized range test and Waller Duncan's test (SAS Institute Inc., 1990).

\section{RESULTS}

Jejunal effluent flow-rate, osmolality and ion concentrations

The jejunal effluent flow-rate $200 \mathrm{~mm}$ below the angle of Treitz was calculated from the PEG concentration and corrected for perfusion flow-rate $(2 \mathrm{ml} / \mathrm{min})$. In the $20 \mathrm{~min}$ preceding meal ingestion, the flow rate was 3.32 (SE 2.96) $\mathrm{ml} / \mathrm{min}(n$ 24) and differed significantly from $0(P<0.05)$. The effluent flow-rate was then measured every $20 \mathrm{~min}$ after meal ingestion (Fig. 1). The flow-rate reached a peak in the $20 \mathrm{~min}$ period following water ingestion, and to a lesser extent in the period $20-40 \mathrm{~min}$ after soymilk or isolate ingestion. The flow-rate progressively returned to the initial value after 80-100 min for water, and 160-180 min for soymilk and isolate. The flow-rate was significantly higher $(P<0.05)$ for water than for isolate and soymilk in the first $20 \mathrm{~min}$ after ingestion and did not differ between the three meals afterwards.

$\mathrm{pH}$, osmolality and ion $\left(\mathrm{Na}^{+}, \mathrm{Cl}^{-}, \mathrm{K}^{+}, \mathrm{Ca}^{2+}, \mathrm{Mg}^{2+}\right)$ concentrations of jejunal effluent were determined for samples pooled over each $20 \mathrm{~min}$ period. In all cases the $\mathrm{pH}$ of the effluents was near 6.4 during the initial period and showed little variation after meal ingestion (not shown). Both osmolality and $\mathrm{NaCl}$ concentrations significantly decreased ( $P$ $<0.05)$ in the $0-40 \mathrm{~min}$ period following water ingestion, and then returned to the initial level (Figs 1 and 2). In contrast, for both isolate and soymilk the osmolality did not vary during the test period, the $\mathrm{Na}^{+}$concentration decreased slightly and only the $\mathrm{Cl}^{-}$ concentration decreased greatly $(P<0.05)$ during $60 \mathrm{~min}$ but to a lesser extent than with 

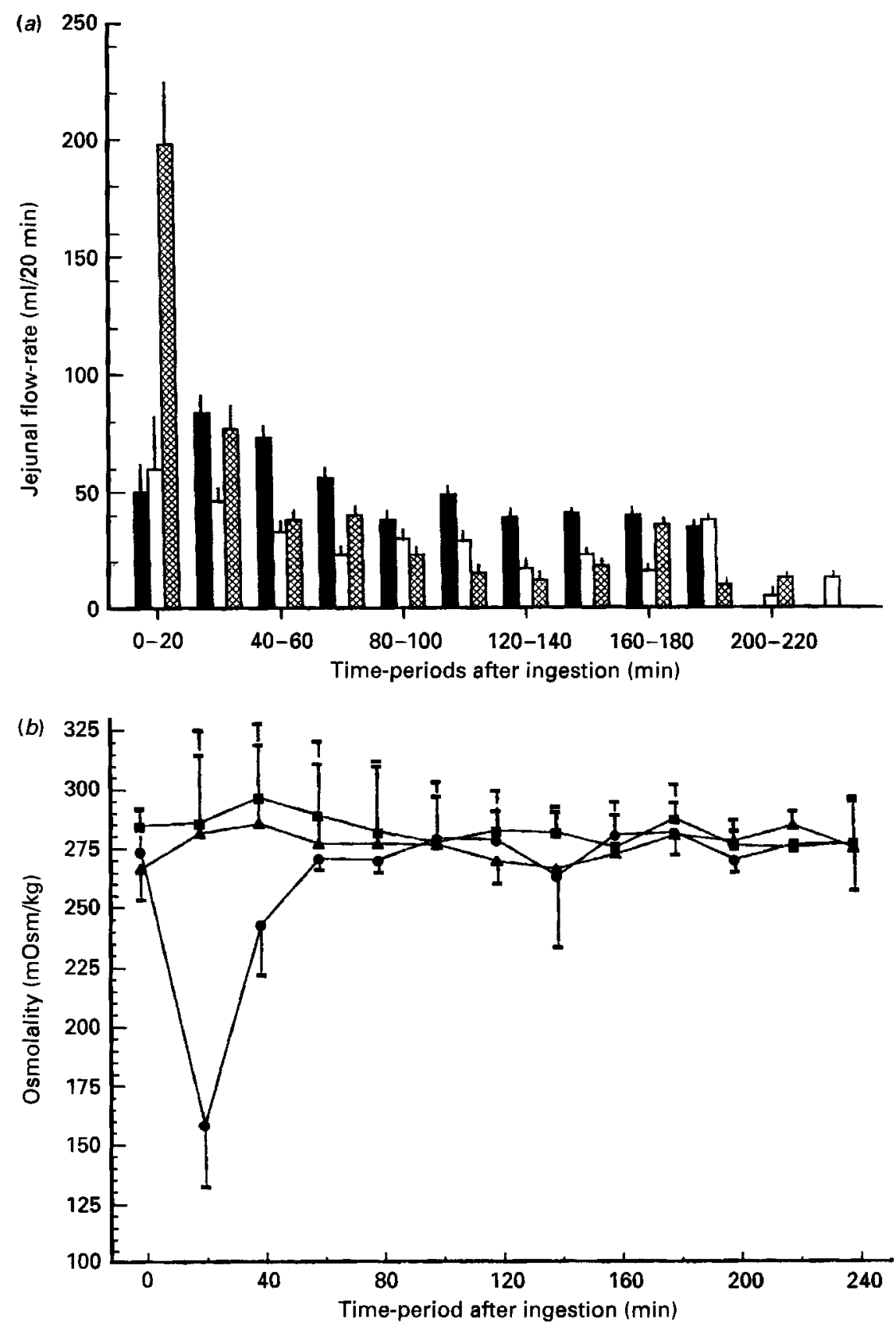

Fig. 1. (a) Effluent flow rate (ml $/ 20 \mathrm{~min} ; \square, \square,($ ) and $(b)$ osmolality (mOsm $/ \mathrm{kg} ; \boldsymbol{\Delta}, \boldsymbol{\square}, \boldsymbol{O})$ profiles of jejunum contents of healthy female volunteers after the ingestion of $400 \mathrm{ml}$ water (control; $⿴, 0$ ), crude soya-bean-protein drink (soymilk; $\mathbf{D}, \mathbf{A}$ ), and concentrated soya-bean-protein solution (isolate; $\square, \square$ ). Values are means with their standard errors represented by vertical bars for eight subjects. For details of test meals and procedures, see Table 1 and pp. 520-522. 

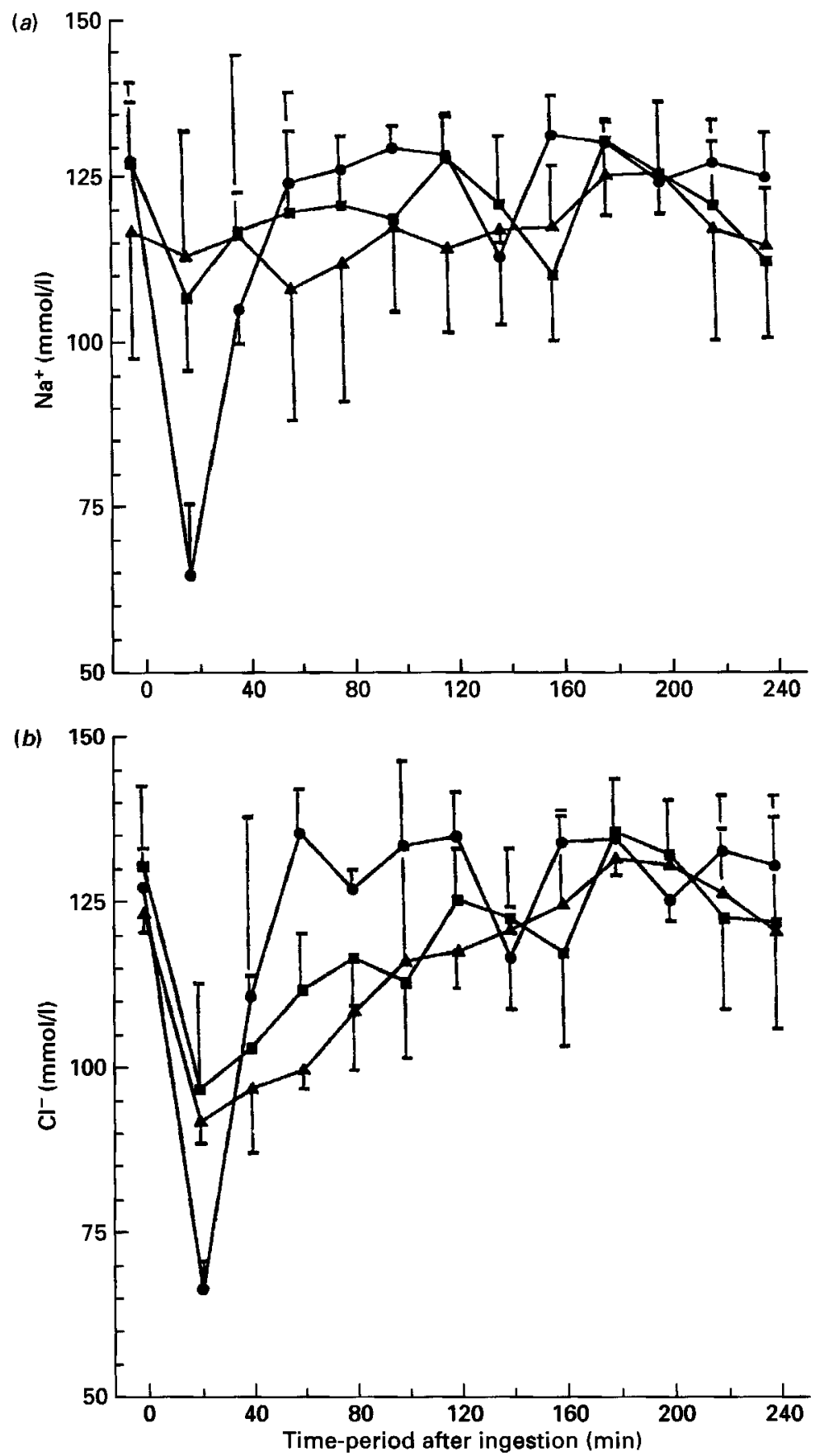

Fig. 2. Effluent $\mathrm{NaCl}$ flow-rate $(\mathrm{mmol} / 20 \mathrm{~min}$ ) profile of jejunum contents of healthy female volunteers after the ingestion of $400 \mathrm{ml}$ water (control; $O$ ), crude soya-bean-protein drink (soymilk; $\Delta$ ) and concentrated soyabean-protein solution (isolate; $\square$ ). Values are means with their standard errors represented by vertical bars for eight subjects. For details of test meals and procedures, see Table 1 and pp. 520-522. 
Table 2. Water and electrolyte movements between the stomach and the jejunum during the $240 \mathrm{~min}$ following the ingestion of $400 \mathrm{ml}$ water (control), a crude soya-bean-protein drink (soymilk) or a concentrated soya-bean-protein solution (isolate) by healthy female volunteers $†$

(Values are means with their standard errors for eight subjects)

\begin{tabular}{|c|c|c|c|c|c|c|c|}
\hline & \multirow[b]{2}{*}{ Ingested } & \multirow[b]{2}{*}{ Perfused } & \multirow{2}{*}{$\begin{array}{l}\text { Total } \\
\text { (a) }\end{array}$} & \multicolumn{2}{|c|}{$\begin{array}{l}\text { Recovered } \\
\text { (b) }\end{array}$} & \multicolumn{2}{|c|}{$\begin{array}{c}\text { Exchange }+ \\
(\mathrm{a}-\mathrm{b})\end{array}$} \\
\hline & & & & Mean & SE & Mean & SE \\
\hline \multicolumn{8}{|l|}{ Volume (ml) } \\
\hline Control & 400 & 480 & 880 & 908.7 & $170 \cdot 1$ & $-28 \cdot 7$ & $170-1$ \\
\hline Isolate & 400 & 480 & 800 & 843.9 & 210.9 & $+36 \cdot 1$ & $210 \cdot 9$ \\
\hline Soymilk & 400 & 480 & 880 & $1007 \cdot 5$ & $140 \cdot 2$ & -127.5 & 140.2 \\
\hline \multicolumn{8}{|l|}{$\mathrm{Cl}^{-}(\mathrm{mmol})$} \\
\hline Control & 0 & 72 & 72 & 85.8 & $26 \cdot 5$ & $-13 \cdot 8$ & $26 \cdot 5$ \\
\hline Isolate & $1 \cdot 2$ & 72 & $73 \cdot 2$ & $90 \cdot 3$ & 35.8 & $-17 \cdot 1$ & 35.8 \\
\hline Soymilk & $1 \cdot 1$ & 72 & $73 \cdot 1$ & 105.8 & $21 \cdot 3$ & $-32 \cdot 7^{*}$ & $21 \cdot 3$ \\
\hline \multicolumn{8}{|l|}{$\mathrm{Na}^{+}(\mathrm{mmol})$} \\
\hline Control & 0.05 & 72 & 72.05 & $84 \cdot 8$ & 25.6 & -12.7 & $25 \cdot 6$ \\
\hline Isolate & $7 \cdot 1$ & 72 & $79 \cdot 1$ & $92 \cdot 8$ & $37 \cdot 0$ & -13.7 & 37.0 \\
\hline Soymilk & $5 \cdot 2$ & 72 & $77 \cdot 2$ & $110 \cdot 2$ & 20.9 & $-33 \cdot 0^{*}$ & $20 \cdot 9$ \\
\hline \multicolumn{8}{|l|}{$\mathrm{K}^{+}(\mathrm{mmol})$} \\
\hline Control & 0.06 & 0 & 0.06 & $3 \cdot 4$ & $1 \cdot 1$ & $-3 \cdot 3^{*}$ & $1 \cdot 1$ \\
\hline Isolate & 0.4 & 0 & 0.4 & $4 \cdot 9$ & $2 \cdot 3$ & $-4 \cdot 5^{*}$ & $2 \cdot 3$ \\
\hline Soymilk & $5 \cdot 8$ & 0 & $5 \cdot 8$ & 6.5 & $2 \cdot 1$ & -0.7 & $2 \cdot 1$ \\
\hline \multicolumn{8}{|c|}{$\mathrm{Ca}^{2+}(\mathrm{mmol})$} \\
\hline Control & $2 \cdot 0$ & 0 & $2 \cdot 0$ & 1.5 & 0.2 & $+0.6 *$ & 0.2 \\
\hline Isolate & 0.7 & 0 & 0.7 & $0 \cdot 3$ & 0.1 & $+0.4^{*}$ & 0.1 \\
\hline Soymilk & 1.9 & 0 & 1.9 & $0 \cdot 3$ & 0.2 & $+1 \cdot 6^{*}$ & $0 \cdot 2$ \\
\hline \multicolumn{8}{|c|}{$\mathrm{Mg}^{2+}(\mathrm{mmol})$} \\
\hline Control & 0.6 & 0 & 0.6 & 0.7 & 0.1 & -0.1 & $0 \cdot 1$ \\
\hline Isolate & 0.4 & 0 & 0.4 & 0.5 & 0.2 & -0.1 & 0.2 \\
\hline Soymilk & $2 \cdot 0$ & 0 & $2 \cdot 0$ & $1 \cdot 3$ & 0.1 & +0.8 & $0 \cdot 1$ \\
\hline
\end{tabular}

* Mean values were significantly different from 0 , Student's $t$-test; $P<0.05$

$\dagger$ For details of test meals and procedures, see Table 1 and pp. 520-522.

$\ddagger \mathbf{A}$ positive value indicates an absorption, and a negative value indicates a secretion.

water. The $\mathrm{K}^{+}$concentration did not vary after isolate ingestion but increased significantly $(P<0.05)$ in the $20-60$ min period after soymilk ingestion.

The estimates of water and $\mathrm{NaCl}$ movement between the stomach and the jejunum in the 240 min period following ingestion indicated a significant apparent secretion of $\mathrm{NaCl}$ only after soymilk ingestion (Table 2). In the same way, a significant apparent secretion of $\mathrm{K}^{+}$ was observed after soymilk and water ingestion. In addition, a significant absorption of $\mathrm{Ca}^{2+}$ was observed following the three test meals.

Gastric emptying and transit of the liquid phase of the meal

Gastric emptying and passage of the liquid phase through the jejunum for the two different meals and water were calculated by measuring the disappearance of gastric ${ }^{14} \mathrm{C}-\mathrm{PEG}$ radioactivity and its appearance in the jejunum (Fig. 3). The liquid phase completely disappeared from the stomach $140 \mathrm{~min}$ after meal ingestion (Fig. 3(a)). The gastric emptying pattern could be described using the power exponential curve $\mathrm{V}=\exp \left(-a t^{b}\right)$ 

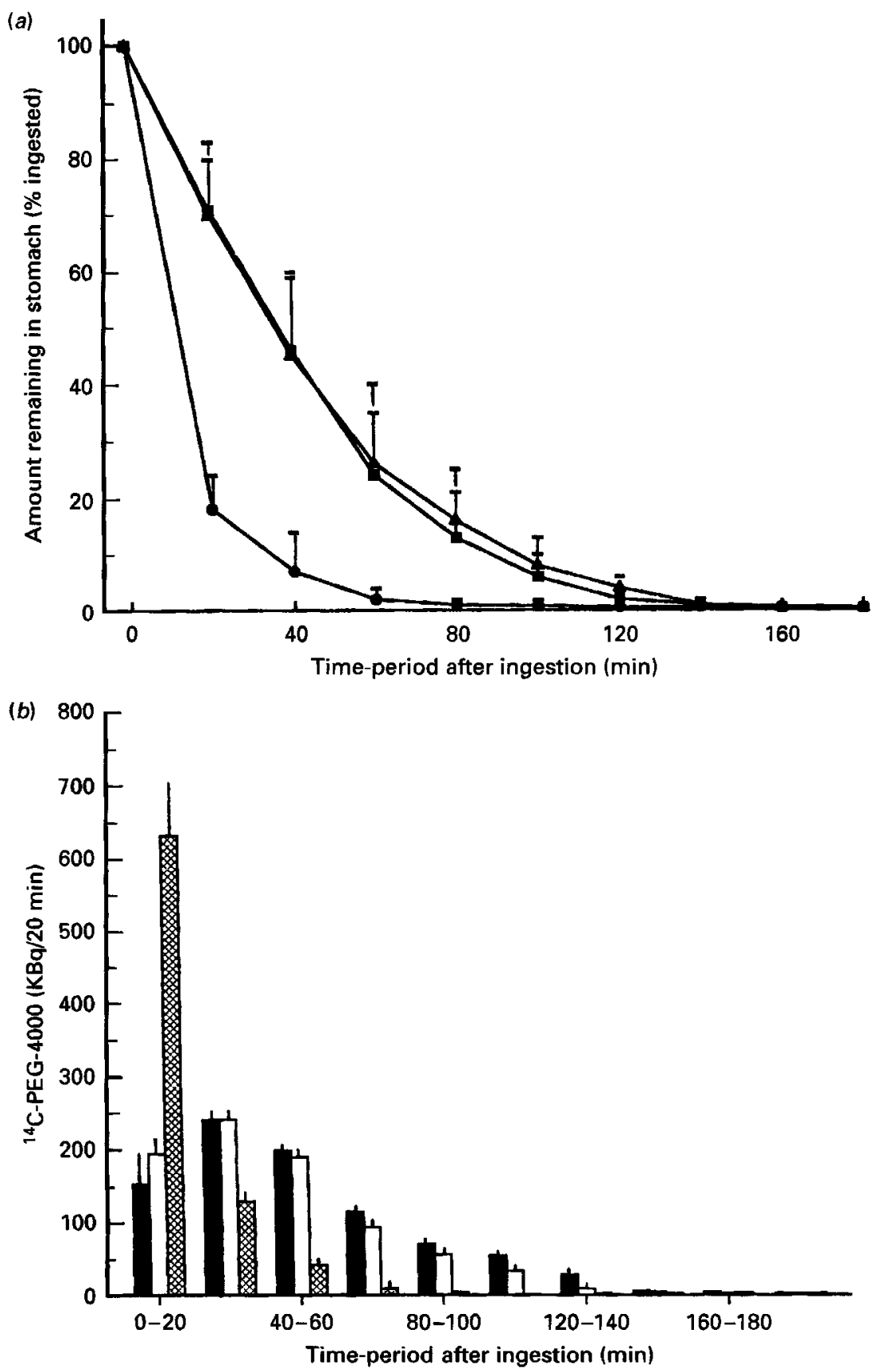

Fig. 3. (a) Gastric emptying pattern $(\% ; \mathbf{\Delta}, \boldsymbol{a}, \boldsymbol{O})$ and $(b)\left[{ }^{14} \mathrm{C}\right]$ polyethylene glycol (molecular weight $4000 ;{ }^{14} \mathrm{C}$. PEG-4000; $\mathbf{\square}, \square, \mathbb{Q}$ ) concentration profile $(\mathrm{kBq} / 20 \mathrm{~min})$ of the liquid phase after the ingestion of $400 \mathrm{ml}$ water (control;, $\mathbf{Q}$, ), crude soya-bean-protein drink (soymilk; $\boldsymbol{\Delta}, \mathbf{\square}$ ) and concentrated soya-bean-protein solution (isolate;,$\square$ ) by healthy female volunteers. Values are means with their standard errors represented by vertical bars for eight subjects. Gastric half-emptying time $(\mathrm{min})$ was significantly different (Tukey's studentized range test; $P<0.05)$ between water $(12.6$ (SE 0.1)) and soymilk (37.7 (SE 11.6)) and isolate (36.5 (SE 11.2)). For details of test meals and procedures, see Table 1 and pp. 520-522. 

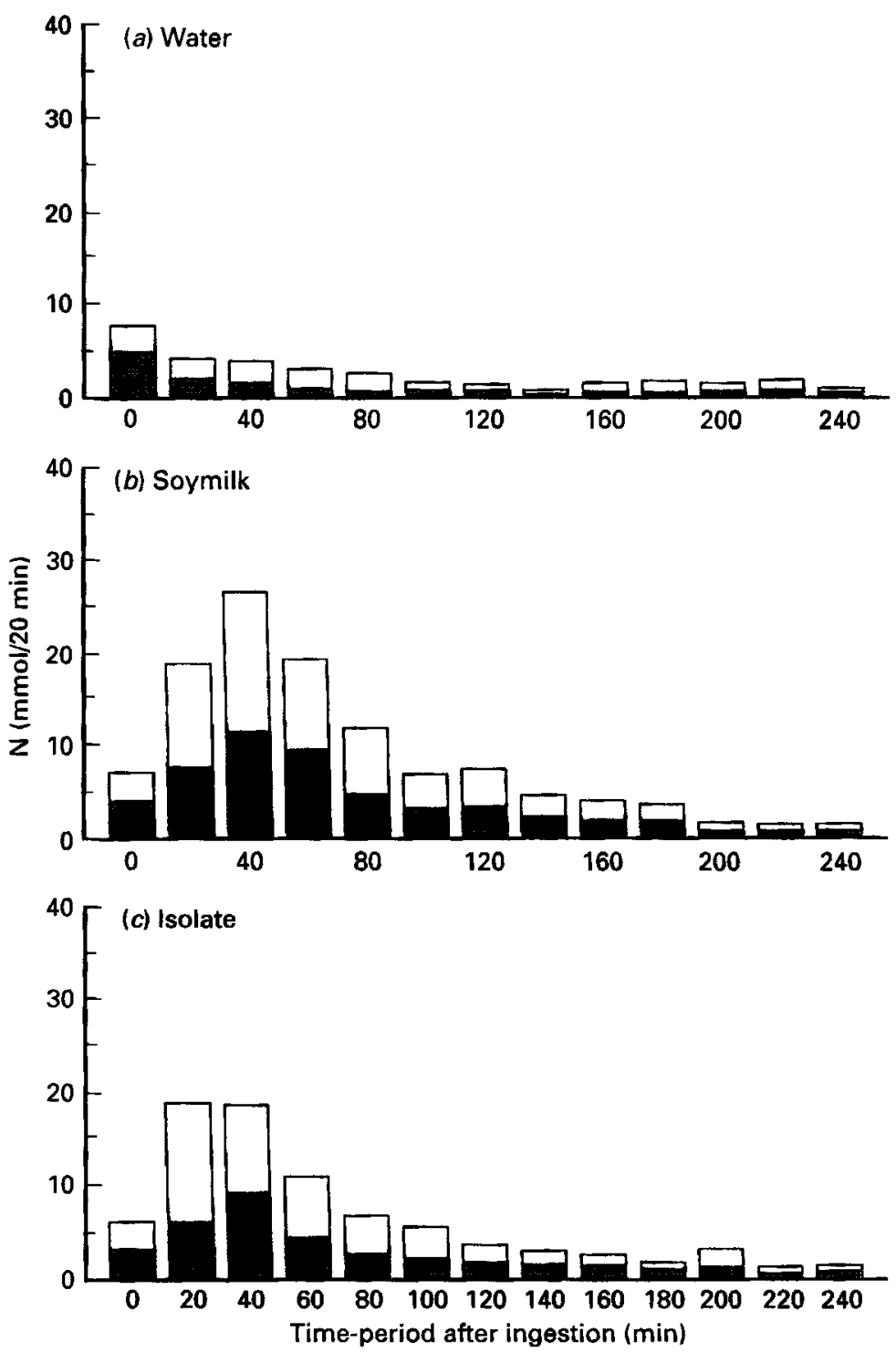

Fig. 4. Total nitrogen profile ( $\mathrm{mmol} / 20 \mathrm{~min}$ ) of alcohol-soluble ( $\square$ ) and alcohol-insoluble (国) fractions of the digesta in jejunum of healthy female volunteers after the ingestion of (a) $400 \mathrm{ml}$ water (control), (b) crude soyabean-protein drink (soymilk), and (c) concentrated soya-bean-protein solution (isolate). Values are means with their standard errors represented by vertical bars for eight subjects. For details of test meals and procedures, see Table 1 and pp. 520-522.

(Elashoff et al. 1982). The power parameter $b$ significantly differed $(P<0.05)$ from 1 for isolate (1.42 (SE 0.28)) and soymilk (1.33 (SE 0.2)) but not for water (1.08 (SE 0.41)), which exhibited a simple exponential emptying pattern. The half-emptying time of the liquid phase of water $(12.59$ (SE 0.12$)$ min) was significantly different $(P<0.05)$ from those of soymilk (37.74 (SE 11.57)) and isolate (36.52 (SE 11.23) min). In parallel, ${ }^{14} \mathrm{C}-\mathrm{PEG}$ rapidly appeared in the jejunum after water ingestion whereas it was delayed after soya-beanprotein ingestion (Fig. 3(b)). Jejunal ${ }^{14} \mathrm{C}-\mathrm{PEG}$ radioactivity reached its maximum level 
Table 3. Amino acid composition $(\mathrm{mg} / \mathrm{g}$ ) of endogenous nitrogen and crude soya-bean-protein drink (soymilk) and in the jejunum during the 140 min following ingestion of $400 \mathrm{ml}$ soymilk by healthy female volunteers*

(Mean values with their standard errors for eight subjects)

\begin{tabular}{|c|c|c|c|c|c|c|}
\hline & \multicolumn{2}{|c|}{$\begin{array}{l}\text { Endogenous } \\
\text { effluents }\end{array}$} & \multicolumn{2}{|c|}{ Soymilk } & \multicolumn{2}{|c|}{$\begin{array}{l}\text { Soymilk } \\
\text { effluents }\end{array}$} \\
\hline & Mean & SE & Mean & SE & Mean & SE \\
\hline Asp & $96 \cdot 7^{\mathrm{a}}$ & 6.9 & $113 \cdot 4^{\mathrm{b}}$ & $2 \cdot 5$ & $114 \cdot 2^{b}$ & $3 \cdot 0$ \\
\hline Thr & $63 \cdot 7^{\mathrm{g}}$ & 3.0 & $43.9^{b}$ & 0.4 & $50.1^{c}$ & 3.6 \\
\hline Ser & $62 \cdot 6^{\mathrm{a}}$ & 2.7 & $57 \cdot 4^{b}$ & $0 \cdot 3$ & $57 \cdot 2^{\mathrm{b}}$ & 2.8 \\
\hline Glu & $116 \cdot 0^{\mathrm{a}}$ & 0.8 & $185 \cdot 6^{\mathrm{b}}$ & 7.6 & $167 \cdot 0^{\mathrm{b}}$ & $9 \cdot 3$ \\
\hline Pro & $73 \cdot 6^{a}$ & 5.8 & $57 \cdot 4^{\mathrm{b}}$ & 1.4 & $61 \cdot 3^{b}$ & 5.4 \\
\hline Gly & $56 \cdot 3^{a}$ & $6 \cdot 3$ & $43 \cdot 0^{\mathrm{b}}$ & 0.4 & $70 \cdot 6^{c}$ & $7 \cdot 0$ \\
\hline Ala & $49 \cdot 5^{\mathrm{a}}$ & 0.9 & $44 \cdot 9^{b}$ & 0.6 & $43 \cdot 8^{b}$ & 0.9 \\
\hline Val & $62 \cdot 7^{\mathrm{a}}$ & $1 \cdot 2$ & $42 \cdot 9^{b}$ & 0.7 & $51 \cdot 4^{b}$ & 1.9 \\
\hline Met & $14 \cdot 2^{a}$ & 1.4 & $14 \cdot 8^{\mathrm{a}}$ & 0.4 & $13 \cdot 8^{\mathrm{a}}$ & 0.3 \\
\hline Ile & $44 \cdot 9^{\mathrm{a}}$ & 3.0 & $43 \cdot 5^{a}$ & 0.7 & $47 \cdot 2^{\mathrm{a}}$ & $2 \cdot 2$ \\
\hline Leu & $93 \cdot 5^{\mathrm{a}}$ & $4 \cdot 1$ & $83 \cdot 3^{a}$ & 1.2 & $79 \cdot 3^{\mathrm{e}}$ & 1.6 \\
\hline Tyr & $60 \cdot 0^{a}$ & $2 \cdot 4$ & $38 \cdot 7^{\mathrm{b}}$ & $1 \cdot 1$ & $40 \cdot 5^{b}$ & 1.2 \\
\hline Phe & $63 \cdot 3^{a}$ & $4 \cdot 3$ & $52 \cdot 5^{\mathrm{b}}$ & 1.4 & $47 \cdot 8^{b}$ & $4 \cdot 4$ \\
\hline His & $28 \cdot 8^{\mathrm{a}}$ & 0.4 & $28 \cdot 4^{\mathrm{a}}$ & 0.5 & $27 \cdot 7^{a}$ & 0.7 \\
\hline Lys & $59 \cdot 0^{\mathrm{s}}$ & $2 \cdot 5$ & $66 \cdot 9^{b}$ & 0.1 & $63 \cdot 3^{c}$ & $2 \cdot 0$ \\
\hline Arg & $55 \cdot 3^{a}$ & 1.2 & $83 \cdot 4^{b}$ & $1 \cdot 5$ & $64 \cdot 7^{\mathrm{e}}$ & 8.1 \\
\hline
\end{tabular}

a, b, c Mean values with the same superscript letter were not statistically different (Waller Duncan test; $P<$ 0.05).

* For details of test meals and procedures, see Table 1 and pp. 520-522.

during the first $20 \mathrm{~min}$ after water ingestion and during the first $40 \mathrm{~min}$ after isolate and soymilk ingestion.

\section{Nitrogen and amino acids}

The ethanol-soluble and -insoluble fractions as well as total $\mathrm{N}$ were measured in the meals and in the jejunal effluents every $20 \mathrm{~min}$ after either water (endogenous $\mathrm{N}$ ), soymilk or isolate ingestion (Fig. 4). Before the ingestion of test meals the average initial $\mathrm{N}$ flow-rate in the jejunum was 20.71 (SE $2 \cdot 14) \mathrm{mmol} / \mathrm{h}(n 24)$. Total $\mathrm{N}$ content of the jejunal effluents remained unchanged after water ingestion (Fig. $4(a)$ ), but reached a peak during 0-40 min after isolate ingestion (Fig. 4(b)) and during 20-40 min after soymilk ingestion (Fig. 4(c)), and progressively returned to the initial level. Ethanol precipitation gave an estimation of the balance between protein (insoluble) and peptide or amino acid (soluble) fractions. The ethanol-insoluble fraction of soymilk and isolate represented 63.4 and $98.8 \%$ of the total $\mathrm{N}$ respectively. The ethanol-soluble fraction represented about $46 \%$ of total $\mathrm{N}$ before meal ingestion, reached a peak of $68-70 \%$ during the first $60 \mathrm{~min}$ period following water ingestion, $62 \%$ during the $0-20 \mathrm{~min}$ period following isolate ingestion, and $58 \%$ during the $0-40 \mathrm{~min}$ period following soymilk ingestion and progressively returned to $47 \%$ in $2 \mathrm{~h}$ after soymilk and isolate ingestion.

The amino acid composition of the intestinal effluents collected during the $140 \mathrm{~min}$ following soymilk ingestion was compared with those of the soymilk meal and the intestinal effluents collected after water ingestion (endogenous $\mathrm{N}$; Table 3). Soymilk was rich in aspartic and glutamic acid and contained small amounts of methionine. No difference between soymilk and intestinal effluents was noticed for methionine, isoleucine and 
histidine. The amino acid composition of the effluents collected after soymilk ingestion did not differ from that of soymilk but differed from that of endogenous $\mathrm{N}$ (after water ingestion) for aspartic acid, serine, glutamic acid, proline, alanine, valine, tyrosine and phenylalanine. The three samples were significantly different from one another for threonine, glycine, leucine, lysine and arginine. The comparison of the compositions of (1) soymilk effluents, (2) soymilk meal and (3) endogenous $N$ was performed using the iterative procedure (Guilloteau et al. 1983) and indicated that the soymilk effluents were of exogenous and endogenous origins, 70 and $30 \%$ respectively.

\section{DISCUSSION}

Protein digestibility is important in terms of protein quality for food legumes. Digestibility and bioavailability of legumes proteins are often believed to be less than those obtained for animal proteins. The present work was performed to study the gastro-jejunal behaviour of two forms of soya-bean protein, isolate (a concentrated soya-bean protein solution) and soymilk (a drink composed of crude soya-bean protein) and to estimate their true jejunal digestibility before colonic bacterial fermentation. For that purpose, healthy volunteers were intubated with a double-lumen tube to allow for both collection in the proximal jejunum and quantification of the main gastro-jejunal movement of water, electrolytes and $\mathbf{N}$ during digestion and absorption of test meals.

Water (control) and the two test meals can be divided into two groups according to the gastric emptying rate: (1) water which leaves the stomach very quickly and (2) soymilk and isolate which have delayed gastric emptying times compared with water. The gastric halfemptying times (min) observed for water $(12.6)$, isolate $(36.5)$ and soymilk $(37.7)$ are very close to those previously obtained for water and protein solutions. Indeed, Hunt \& McDonald (1954) found a gastric half-emptying time of $10 \mathrm{~min}$ after the ingestion of $500 \mathrm{ml}$ water. Ruskoné et al. (1980) obtained a gastric half-emptying time of $36 \mathrm{~min}$ after the ingestion of $15 \mathrm{~g}$ beef proteins diluted in $400 \mathrm{ml}$ water. Similar results were obtained in studies of the digestive behaviour of cow's milk where gastric half-emptying times of water $(400 \mathrm{ml})$ and skim milk $(12.8 \mathrm{~g}$ proteins $/ 400 \mathrm{ml})$ were 9 and $25 \mathrm{~min}$ respectively (Mahé et al. 1992). The slower gastric emptying of soymilk and isolate in comparison with water could be explained by hormonal, energetic and osmotic effects due to the presence of either proteins, lipids (Moberg \& Calberger, 1974; Houghton et al. 1990) or carbohydrates (Brener et al. 1983).

In the initial state, water, $\mathrm{Na}^{+}$and $\mathrm{Cl}^{-}$secretion were present at the jejunum level. In fact there was a continuous exchange of water and electrolytes all along the intestine in order to regulate the osmolality and the composition of the lumen contents (Fordtran \& Locklear, 1966; Emonts et al. 1979). The values obtained in the lumen for the $\mathrm{K}^{+}, \mathrm{Ca}^{2+}$ and $\mathrm{Mg}^{2+}$ concentrations were representative of meal composition. The gastro-jejunal electrolytic balances for $\mathrm{Na}^{+}, \mathrm{Cl}^{-}, \mathrm{K}^{+}, \mathrm{Ca}^{2+}$ and $\mathrm{Mg}^{2+}$ showed the quantity of ions associated with the meals and the quantity of $\mathrm{Na}^{+}$and $\mathrm{Cl}^{-}$perfused. For the soymilk, $\mathrm{NaCl}$ was secreted whereas $\mathrm{Ca}^{2+}$ was well absorbed from the jejunal lumen. This result is in accordance with that of Fordtran \& Locklear (1966) who observed a net water secretion into the duodenum and the proximal jejunum after milk ingestion, concomitant with $\mathrm{NaCl}$ movement. The same authors have noted a marked decrease in dissolved $\mathrm{Ca}^{2+}$ along the lumen. For water and isolate, $\mathrm{K}^{+}$was secreted in large amounts, reaching a value close to $6 \mathrm{mmol} / \mathrm{l}$. However, with soymilk, no significant quantity of this ion was secreted from the jejunum due to its high concentration in the meal.

The $\mathrm{N}$ recovered in the jejunal effluents originated from both food and endogenous secretion. Water ingestion had a washing effect involving $21 \mathrm{mmol} \mathrm{N}$ during the $140 \mathrm{~min}$ 
Table 4. Estimation of the gastro-jejunal nitrogen absorption balance in human jejunum during the $140 \mathrm{~min}$ following ingestion of $400 \mathrm{ml}$ water (control), crude soya-bean-protein drink (soymilk) or concentrated soya-bean-protein solution (isolate) by healthy female volunteers*

(Mean values with their standard errors for eight subjects)

\begin{tabular}{|c|c|c|c|c|c|c|c|c|c|}
\hline & \multirow{3}{*}{$\begin{array}{c}\text { Ingested } \\
(\mathrm{mmol})\end{array}$} & & & \multicolumn{6}{|c|}{ Absorption (\%) } \\
\hline & & \multicolumn{2}{|c|}{ Recovered (mmol) } & \multicolumn{2}{|c|}{ Apparent $\dagger$} & \multicolumn{2}{|c|}{ Corrected $\ddagger$} & \multicolumn{2}{|c|}{ Net§ } \\
\hline & & Mean & $\mathrm{SE}$ & Mean & SE & Mean & SE & Mean & $\mathrm{SE}$ \\
\hline \multirow{3}{*}{$\begin{array}{l}\text { Control } \\
\text { Isolate } \\
\text { Soymilk }\end{array}$} & 0 & $20 \cdot 8$ & $3 \cdot 3$ & \multicolumn{2}{|c|}{ - } & \multicolumn{2}{|c|}{-} & \multicolumn{2}{|c|}{ - } \\
\hline & 146 & $75 \cdot 0$ & $20 \cdot 2$ & $48 \cdot 6$ & $13 \cdot 8$ & $62 \cdot 9$ & $13 \cdot 8$ & & \\
\hline & 161 & $102 \cdot 3$ & 28.9 & $36 \cdot 4$ & $18 \cdot 0$ & $49 \cdot 4$ & $18 \cdot 0$ & $54 \cdot 1$ & 13.6 \\
\hline
\end{tabular}

* For details of test meals and procedures, see Table 1 and pp. 520-522.

$\dagger$ Calculated from $(1-$ (total $\mathrm{N}$ recovered/ $\mathrm{N}$ ingested $))$.

$\$$ Calculated from $(1-(($ total $N$ recovered $-A) / N$ ingested $))$, where $A$ is the total $\mathrm{N}$ recovered after water ingestion which was used to estimate endogenous $\mathrm{N}$ secretion and was estimated as $20.8 \mathrm{mmol}$.

$\S$ Exogenous $\mathrm{N}$ fraction of jejunal effluents after soymilk ingestion was estimated by amino acid compositions to be $67 \%$; by this method, the exogenous $\mathrm{N}$ fraction after soymilk ingestion was 73.9 (SE 21.9 ) mmol and net absorption was calculated as $(1-$ (exogenous $\mathrm{N}$ recovered/ $\mathrm{N}$ ingested)).

period, which represents basal endogenous protein secretion since the water meal did not contain any exogenous protein. The value of $21 \mathrm{mmol}$ endogenous protein in the jejunum was in accordance with previous studies in humans where basal secretion of endogenous $\mathrm{N}$ was 16-20 mmol in $140 \mathrm{~min}$ (Mahé et al. 1992, 1994). Using this value to quantify endogenous $\mathrm{N}$, gastro-jejunal $\mathrm{N}$ absorption for isolate and soymilk was 63 and $49 \%$, respectively, and the values were not significantly different (Table 4). Interestingly, after soymilk and isolate ingestion the total amount of $\mathrm{N}$ increased but the ethanol-insoluble fraction (protein-N) decreased from approximately 50 to $30 \%$, whereas soymilk and isolate meals contained 63.4 and $98.8 \%$ ethanol-insoluble fraction respectively. These results strongly suggest that most of the ingested soya-bean proteins were rapidly hydrolysed and converted to ethanol-soluble peptides.

The gastro-jejunal $\mathbf{N}$ absorption balance calculated using basal endogenous protein secretion was probably overestimated, as endogenous secretion is often stimulated by the meal and especially by proteins. In fact, according to the iterative analysis of the amino acid composition of the effluents, the endogenous $\mathrm{N}$ fraction represented $30 \%$ following soymilk ingestion. Under these conditions, $31 \mathrm{mmol}$ endogenous $\mathrm{N}$, which was not significantly different from the $21 \mathrm{mmol}$ obtained after water ingestion, were secreted in the $140 \mathrm{~min}$ following soymilk ingestion. Thus, the gastro-jejunal absorption of soymilk represented $54 \%$ of the protein. Therefore, our results indicate that the ingestion of $15 \mathrm{~g}$ soya-bean proteins induced an additional secretion of $10 \mathrm{mmol}$ (approximately $60 \mathrm{mg}$ protein) of endogenous $\mathrm{N}$ in comparison with water ingestion. Trypsin inhibitors constitute $60 \mathrm{mg} / \mathrm{g}$ total soya-bean protein (Rackis \& Anderson, 1964; Rackis \& Gumbmann, 1981) and are known to increase endogenous $\mathrm{N}$ losses. However, most of the deleterious effects related to antinutritional compounds (trypsin inhibitors, lectin, etc.) in soya-bean proteins can be removed almost entirely by heat treatment. Moreover, commercial soya-bean products do not retain significant amounts of the trypsin inhibitory activity present in the raw soya-beans (Liener, 1981; Temler et al. 1984; Roebuck, 1987; Liener et al. 1988). In a previous study, using $\left[{ }^{15} \mathrm{~N}\right]$ casein, we demonstrated that a small quantity of protein did 
not significantly stimulate endogenous $\mathrm{N}$ secretion which was $36 \mathrm{mmol}$ after the ingestion of $8 \mathrm{~g}$ casein (Mahé et al. 1994).

Soya-bean proteins represent an interesting source of dietary $\mathrm{N}$ for humans not only because of their good amino acid profile, unusually well balanced for a plant protein (Torun et al. 1981), but also because of their high mineral and vitamin contents, in addition to its high polyunsaturated fatty acid content in high-fat products. Studies in humans consuming soya-bean proteins as the only source of protein have shown that this protein can satisfy most $\mathrm{N}$ requirements (Wayler et al. 1983; Young et al. 1984; Beer et al. 1989). Numerous studies have been performed to evaluate the nutritional effects of soya-bean proteins (Erdman \& Fordyce, 1989). The present work provides both a qualitative and a quantitative description of soya-bean protein digestion in the upper region of the human intestine. Our results indicate that these proteins both reduce gastric emptying and slightly stimulate endogenous $\mathrm{N}$ and electrolyte secretion. These results also indicate that more than half $(54 \%)$ the hydrolysis and absorption of ingested soya-bean protein occurs in the upper human jejunum. These observations are in accordance with previous studies in healthy volunteers showing that $42 \%$ of the milk proteins and $58 \%$ of purified casein were absorbed between the stomach and the proximal jejunum (Mahé et al. 1992, 1994), thus indicating that gastro-jejunal digestibility of soya-bean proteins was close to that of animal proteins such as milk proteins. However, the lower region of the jejunum and the ileum are necessary for the completion of the absorption of soya-bean proteins. In fact, after feeding known quantities of soya-bean proteins and measuring faecal $\mathrm{N}$ losses in humans and rats, previous studies showed that soya-bean protein digestibility was between 74 and $98 \%$ (Bodwell et al. 1980; Wang et al. 1983; Wayler et al. 1983). Further studies are now needed (1) to estimate more precisely the quantity and the nature of endogenous and exogenous $\mathrm{N}$ and (2) to evaluate the gastro-ileal digestibility of soya-bean protein and the precise nature of the fraction that passes through the ileo-caecal valve.

This work was supported in part by grant no. 89 G 0629 from the French Department of Research and Technology, NUTRINOV Compagny and TRIBALLAT Industry. The authors wish to thank Suzanne Salter for her assistance with the English.

\section{REFERENCES}

Beer, W. H., Murray, E., Oh, S. H., Pedersen, H. E., Wolfe, R. R. \& Young, V. R. (1989). A long-term metabolic study to assess the nutritional value of and immunological tolerance to two soy-protein concentrates in adult humans. American Journal of Clinical Nutrition 50, 907-1007.

Bodwell, C. E., Satterlee, L. D. \& Hackler, L. R. (1980). Protein digestibility of the same protein preparations by humans and rat assays and by in vitro enzymic digestion methods. Journal of Nutrition 30, 269-283.

Brener, W., Hendrix, T. R. \& McHugh, P. R. (1983). Regulation of the gastric emptying of glucose. Gastroenterology 85, 76-82.

Bressani, R. \& Elias, L. G. (1977). The problem of legume protein digestibility. In Nutritional Standards and Methods of Evaluation for Food Legume Breeders, pp. 61-72 [L. W. Billingsley, editor]. Ottawa: International Development Research Center.

Cheng, Y. J., Thompson, L. D. \& Brittin, H. C. (1990). Sogurt, a yogurt-like soybean product: development and properties. Journal of Food Science 55, 1178-1179.

Elashoff, J. D., Reedy, T. J. \& Meyer, J. H. (1982). Analysis of gastric emptying data. Gastroenterology 83, 1306-1312.

Emonts, P., Vidon, N., Bernier, J. J. \& Rambaud, J. C. (1979). Etude sur 24 heures des flux liquidiens intestinaux chez l'homme normal par la technique de la perfusion lente d'un marqueur non absorbable. (24-hour intestinal water and electrolyte flow rates in normal man: assessment by the slow marker perfusion technique.) Gastroentérologie Clinique et Biologique 3, 139-146.

Erdman, J. W. \& Fordyce, E. J. (1989). Soy products and the human diet. American Journal of Clinical Nutrition 49, 725-737.

Fordtran, J. S. 91966). Marker perfusion techniques for measuring intestinal absorption in man. Gastroenterology 51, 1089-1093. 
Fordtran, J. S. \& Locklear, T. W. (1966). Ionic constituents and osmolality of gastric and small-intestinal fluids after eating. American Journal of Digestive Diseases 11, 503-521.

Grant, G. (1989). Anti-nutritional effects of soyabean: A review. Progress in Food and Nutrition Science 13, $317-348$.

Gorimar, T. S., Hernandez, H. A. \& Polczynski, M. W. (1984). Rapid protein determination using pyrochemiluminescence. American Clinical Products Review November, 46-49.

Guilloteau, P., Sauvant, D. \& Patureau-Mirand, P. (1983). Methods of comparing amino acid composition of proteins: application to undigested proteins in the preruminant calf. Annals of Nutrition and Metabolism 27, 457-469.

Houghton, L. A., Mangnall, Y. F. \& Read, N. W. (1990). Effect of incorporating fat into a liquid test meal on the relation between intragastric distribution and gastric emptying in human volunteers. Gut 31, 1226-1229.

Hunt, J. N. \& McDonald, I. (1954). The influence of volume on gastric emptying. Journal of Physiology 126, 459-474.

Hyden, S. (1955). A turbidimetric method for the determination of higher polyethylene glycols in biological materials. Annals of the Royal Agriculture College of Sweden 21, $139-145$.

Liener, I. E. (1981). Factors affecting the nutritional quality of soya products. Journal of the American Oil Chemists' Society 58, 406-415.

Liener, I. E., Goodale, R. L., Deshmukh, A., Satterberg, T. L., Ward, G., DiPietro, C. M., Bankey, P. E. \& Borner, J. W. (1988). Effect of a trypsin inhibitor from soybeans (Bowman-Birk) on the secretory activity of the human pancreas. Gastroenterology 94, 419-427.

Mahé, S., Huneau, J. F., Marteau, P., Thuillier, F. \& Tomé, D. (1992). Gastro-ileal and electrolyte movements after bovine milk ingestion in humans. American Journal of Clinical Nutrition 56, 410-416.

Mahé, S., Roos, N., Benamouzig, R., Sick, H., Baglieri, A., Huneau, J. F. \& Tomé, D. (1994). True exogenous and endogenous nitrogen fractions in the human jejunum after ${ }^{15} \mathrm{~N}$-labeled casein ingestion in low amounts. Journal of Nutrition 124, 548-555.

Malagelada, J. R., Longstreth, G. F., Summerskill, W. H. J. \& Go, V. L. W. (1976). Measurement of gastric functions during digestion of ordinary solid meals in man. Gastroenterology 70, 203-210.

Moberg, S. \& Calberger, G. (1974). The effect of gastric emptying of test meals with various fat and osmolar concentrations. Scandinavian Journal of Gastroenterology 9, $29-32$.

Modigliani, R., Rambaud, J. C. \& Bernier, J. J. (1973). The method of intraluminal perfusion of the human small intestine. I. Principle and technique. Digestion 9, 176-192.

Rackis, J. J. \& Anderson, R. L. (1964). Isolation of four trypsin inhibitors by DEAE-cellulose chromatography. Biochemical and Biophysical Research Communications 15, 230-235.

Rackis, J. J. \& Gumbmann, M. R. (1981). Protease inhibitors: physiological properties and nutritional significance. In Antinutrients and Natural Toxicants in Foods, pp. 203-237 [R. L. Ory, editor]. Westport, CT: Food and Nutrition Press.

Roebuck, B. D. (1987). Trypsin inhibitors: potential concern for humans? Journal of Nutrition 117, 398-400.

Ruskoné, A., Cosnes, J., Vidon, N., Couzigou, P. \& Bernier, J. J. (1980). Sécrétion et vidange gastrique après différents repas homogénéisés chez l'homme. (Gastric emptying and gastric secretion after variable homogenized meals in man.) Gastroentérologie Clinique et Biologique 4, 777-785.

SAS Institute Inc. (1990). SAS/STAT TM User's Guide, Release 6.03. Cary, NC: SAS Institute Inc.

Taylor, S. L., Lemanske, R. F., Bush, R. K. \& Busse, W. W. (1987). Chemistry of food allergens. In Food Allergy [R. K. Chandra, editor]. St John's, Newfoundland: Nutrition Research Education Foundation.

Temler, R. S., Dormond, C. A., Simon, E., Morel, B. \& Mettraux, C. (1984). Response of rat pancreatic proteases to dietary proteins, their hydrolysates and soybean trypsin inhibitor. Journal of Nutrition 114, 270-278.

Torun, B., Viteri, F. E. \& Young, V. R. (1981). Nutritional role of soya protein for humans. Journal of the American Oil Chemists' Society 58, 400-405.

Vidon, N., Muschart, J. M., Cosnes, J., Ruskoné, A. \& Bernier, J. J. (1979). Etude critique de l'estimation de la vidange gastrique par la méthode de perfusion duodénale d'une substance non absorbable à faible débit. (A critical study of gastric emptying by the dilution of a non-absorbable substance perfused in the duodenum at a slow flow rate.) Gastroentérologie Clinique et Biologique 3, 549-552.

Wang, M. F., Kishi, K., Takahashi, T., Komatsu, T., Ohnaka, M. \& Inoue, G. (1983). Efficiency of utilization of soy protein isolate in Japanese young men. Journal of Nutritional Science and Vitaminology 29, 201-216.

Wayler, A., Queiror, E., Scrimshaw, N. S., Steinke, F. H., Rand, W. M. \& Young V. R. (1983). Nitrogen balance studies in young men to assess the protein quality of an isolated soy protein in relation to meat proteins. Journal of Nutrition 113, 2385-2391.

Wolf, W. J. (1981). Progress and future needs for research in soya protein utilization and nutrition. Journal of the American Oil Chemists' Society 58, 467-473.

Young, V. R., Scrimshaw, N. S., Torun, B. \& Viteri, F. (1979). Soybean protein in human nutrition: an overview. Journal of the American Oil Chemists' Society 56, 110-120.

Young, V. R., Wayler, A., Garza, C., Steinke, F. H., Murray, E., Rand, W. M. \& Scrimshaw, N. S. (1984). A long term metabolic balance study in young men to assess the nutritional quality of an isolated soy protein and beef proteins. American Journal of Clinical Nutrition 39, 8-15. 